\title{
Acute Injections of the NMDA Receptor Antagonist Memantine Rescue Performance Deficits of the Ts65Dn Mouse Model of Down Syndrome on a Fear Conditioning Test
}

\author{
Alberto CS Costa*, ${ }^{*, 2,3}$, Jonah J Scott-McKean ${ }^{3}$ and Melissa R Stasko' \\ 'Division of Clinical Pharmacology and Toxicology, Department of Medicine, University of Colorado at Denver and Health Sciences Center, \\ Denver, CO, USA; ${ }^{2}$ Department of Psychiatry, University of Colorado at Denver and Health Sciences Center, Denver, CO, USA; ${ }^{3}$ Neuroscience \\ Training Program, University of Colorado at Denver and Health Sciences Center, Aurora, CO, USA
}

Individuals with Down syndrome (DS) and Ts65Dn mice (a major animal model of DS) carry an extra copy of the DSCRI (Down Syndrome Critical Region I) gene, which encodes for a protein that inhibits calcineurin. Calcineurin itself has been shown to modulate $\mathrm{N}$-methyl-D-aspartate (NMDA) receptor (NMDAR) activation kinetics by decreasing channel mean open time and opening probability. We hypothesize that the overexpression of DSCRI in persons with DS and Ts65Dn mice would inhibit normal calcineurin activity and produce pathological increases in NMDAR mean open time and opening probability. These kinetic changes should in turn produce an increase in inhibition of NMDAR-mediated currents by open channel blockers. To test this hypothesis, we investigated the locomotorstimulating effects of MK-80I on Ts65Dn mice and have found that these mice display an increased sensitivity to this compound. Furthermore, we have found that acute injections $(5 \mathrm{mg} / \mathrm{kg}$, i.p.) of the uncompetitive NMDAR antagonist memantine rescue performance deficits of Ts65Dn mice on a fear conditioning test. Because the actions of memantine on NMDAR kinetics had been shown by others to mimic somewhat the actions of calcineurin, we attributed this positive effect of memantine on Ts65Dn mice to a drug-mediated 'normalization' of NMDAR function. To our knowledge, this is the first instance in which the acute injection of a pharmacological agent has improved the behavioral performance of Ts65Dn mice in a test of learning and memory. These results are very promising from a potential therapeutic perspective, given memantine's current status as a Food and Drug Administration (FDA)approved drug.

Neuropsychopharmacology (2008) 33, 1624-1632; doi:I0.I038/sj.npp. I 301535; published online I5 August 2007

Keywords: NMDA receptor; DSCRI; calcineurin; Down syndrome; Alzheimer's disease; memantine

\section{INTRODUCTION}

The trisomy of human chromosome 21 produces Down syndrome (DS), the most common genetically defined cause of intellectual disabilities (reviewed recently by Patterson and Costa, 2005). In addition to its effect on neurodevelopment, DS also has a neurodegenerative component, which includes the universal presence of a neuropathology indistinguishable from Alzheimer's disease (AD) in individuals with DS by age 40 years and high prevalence of earlyonset dementia (Mann et al, 1990; Zigman et al, 1997; Leverenz and Raskind, 1998). Historically, this association between $\mathrm{DS}$ and $\mathrm{AD}$ led to the hypothesis that $\mathrm{a}$

*Correspondence: Dr ACS Costa, Division of Clinical Pharmacology and Toxicology, Department of Medicine, University of Colorado at Denver and Health Sciences Center, 4200 9th Avenue Box C-237, Denver, CO 80262, USA, Tel: + I 303315 1044, Fax: + I 303315 3272, E-mail: Alberto.Costa@UCHSC.edu

Received 16 May 2007; revised 7 July 2007; accepted I 6 July 2007 chromosome 21 gene must be involved in AD (St GeorgeHyslop et al, 1987) and to the demonstration that mutations in the amyloid precursor protein gene, $A P P$, cause earlyonset AD (Goate et al, 1991). Presently, however, the link between increased dosage of $A P P$ and development of $A D$ like pathology and dementia in persons with DS is still far from established.

In 2003, Ermak and Davies hypothesized that another chromosome 21 gene, DSCR1 (Down Syndrome Critical Region 1), may be involved in producing AD-like pathology in persons with DS. Because DSCR1 is an inhibitor of the protein phosphatase calcineurin $(\mathrm{CaN})$, these authors proposed that the overexpression of DSCR1 in the brains of individuals with DS would cause chronic downregulation of CaN activity. In that same year, based on analyses of chromosome 21 genomic data, Gardiner (2003) hypothesized a role for CaN signaling in the pathogenesis of intellectual disabilities associated to DS.

The mouse ortholog of DSCR1, Dscr1, also is present in three copies in the Ts65Dn mouse; the most commonly used 
animal model of DS (Gardiner, 2003). Brain expression levels of Dscr1 in Ts65Dn mice are elevated by $40-70 \%$ (Kahlem et al, 2004). Moreover, the expression of DSCR1 isoforms is elevated and the calcineurin-dependent transcriptional activity of nuclear factor of activated $\mathrm{T}$ cells (NFAT) is decreased in developing hearts and brains of full trisomy 16 (Ts16) mice (Lange et al, 2005). Recently, Arron et al (2006) suggested that the 50\% increased dosages of DSCR 1 and DYRK1A (which encodes for a nuclear serine/ threonine kinase) cooperatively lead to reduced NFAT activity and to many features associated to DS.

$N$-methyl-D-aspartate (NMDA) receptors (NMDARs) are among the targets of CaN. Lieberman and Mody (1994) demonstrated that the pharmacological inhibition of $\mathrm{CaN}$ activity leads to increased NMDAR mean open time and opening probability. Theoretically, such modulation of kinetic parameters should lead to an increase in inhibition of NMDAR-mediated currents by open channel blockers, including the noncompetitive NMDAR antagonist MK-801. Accordingly, Miyakawa et al (2003) reported that conditional CaN null-mutant mice display increased responses to the locomotor-stimulating effects of MK-801.

In the present study, we used behavioral techniques to test two related hypotheses regarding a potential role for NMDARs in the pathogenesis of DS: (1) if CaN activity levels in Ts65Dn brains are reduced sufficiently, Ts65Dn mice should also display increased sensitivity to MK-801; and (2) because the uncompetitive NMDAR antagonist memantine produces changes on NMDAR kinetics that at least qualitatively mimic the actions of $\mathrm{CaN}$ at the single channel level (Chen et al, 1992), this drug may partially restore the physiological function of NMDAR and potentially improve learning and memory in these animals.

\section{MATERIALS AND METHODS}

\section{Animals}

The production of the Ts65Dn mouse has been described previously (Davisson et al, 1990). Mice used in this experiment were generated by standard crossing of male C57BL/6JEi $\times$ C3h/HeSnJ (F1) hybrids with female Ts65Dn mice. For this study, the Ts65Dn colonies were maintained either at the Eleanor Roosevelt Institute at the University of Denver or at the Center for Laboratory Animal Care at the University of Colorado Health Sciences Center on a 12:12 h light/dark cycle with ad lib access to food and water. Animals were housed with their littermates until a week before experimental tests and then singly housed after that. Approximately $50 \%$ of the mice were cytogenetically genotyped (according to methods described in Davisson et al, 1990), the remaining 50\% were genotyped by the quantitative polymerase chain reaction (qPCR) method developed by Liu et al (2003). Only male animals were used in experiments. Mice were also examined by indirect opthalmoscopy and only mice that did not show any sign of retinal degeneration were used. Experiments were performed in accordance with the Guide for the Care and Use of Laboratory Animals as adopted and promulgated by the National Institutes of Health and under the approval of the University of Colorado's Animal Care and Use Committee.

\section{Drugs}

Saline solutions of MK-801 ((+)-5-methyl-10,11-dihydro$5 H$-dibenzo[a,d]cyclohepten-5,10-imine) hydrogen maleate, D-amphetamine sulfate salt, and memantine (1-amino-3,5dimethyladamantan) hydrochloride (all purchased from Sigma, St Louis, MO) were prepared fresh or stored in a $-80^{\circ} \mathrm{C}$ freezer up to a month before the administration. Doses were expressed in $\mathrm{mg} / \mathrm{kg}$ and injected in a volume of $6.25 \mathrm{ml} / \mathrm{kg}$ intraperitoneally (i.p.).

\section{Behavioral Procedures}

Sensitivity to the locomotor-stimulating effects of $M K-801$, amphetamine, and memantine. These methods were modified from Miyakawa et al (2003). Locomotor activity, as the animals habituate to a novel environment, was assessed in a simplified open field apparatus consisting of a clean mouse cage without bedding, food, or water. Data were collected over a 5-h period by two sets of photocell arrays especially adapted to the exterior walls of the mouse cages to record activity in the ' $x$ ' and ' $z$ ' planes (OptoVarimex-Mini, Columbus Instruments, Columbus, $\mathrm{OH}$ ). The test drug was injected $2 \mathrm{~h}$ after the start of data acquisition (time $=0$ in Figure 1a-i), and cage activity was monitored for an additional $3 \mathrm{~h}$. To obtain information about the dose-response relationships for MK-801 in Ts65Dn and control mice, saline-control or single-dose MK-801 injections were administered once a week for five consecutive weeks on 15 animals of each genotype in the following sequence of doses: $0,0.1,0.2,0.4,0.8 \mathrm{mg} / \mathrm{kg}$. Such sequence of doses (from low to high) was designed to minimize the potential development of tolerance. To test for the selectivity of the MK-801 effect, we injected additional groups of Ts65Dn $(n=10)$ and control mice $(n=10)$ with saline-control or amphetamine at four different doses $(1,2$, 3 and $4 \mathrm{mg} / \mathrm{kg}$ ) and recorded locomotor activity as described above. Again, each dose was administered once a week for 5 weeks at progressively higher doses. Finally, we tested the locomotor-stimulating effects of saline-control and four doses of memantine $(5,10,15$ and $25 \mathrm{mg} / \mathrm{kg})$ on additional groups of Ts65Dn $(n=15)$ and euploid control mice $(n=15)$. The injection protocol again involved progressively higher doses, one single injection per week, for 5 weeks. Altogether, 80 animals (40 Ts65Dn and 40 euploid control mice) were used in these experiments. Notice that no animal received more than one type of drug and none of these animals were used in any other behavioral experiment. The age range of the mice in these experiments was $4-7$ months. Total activity, that is, the total number of photocell interruptions during a $5 \mathrm{~min}$ interval, was the primary dependent measure assessed.

Contextual fear conditioning. We tested the capacity for contextual memory of 4- to 6-month-old, and 10- to 14month-old Ts65Dn mice compared to age-matched euploid control mice using a fear conditioning protocol (Sananbenesi et al, 2002; Bardgett et al, 2003). Five groups of 10 mice and one group of eight mice of each genotype were used, totaling 116 animals. Again, no animal was used in more than one behavioral experiment. Experiments were performed as described previously (Sananbenesi et al, 2002) by 

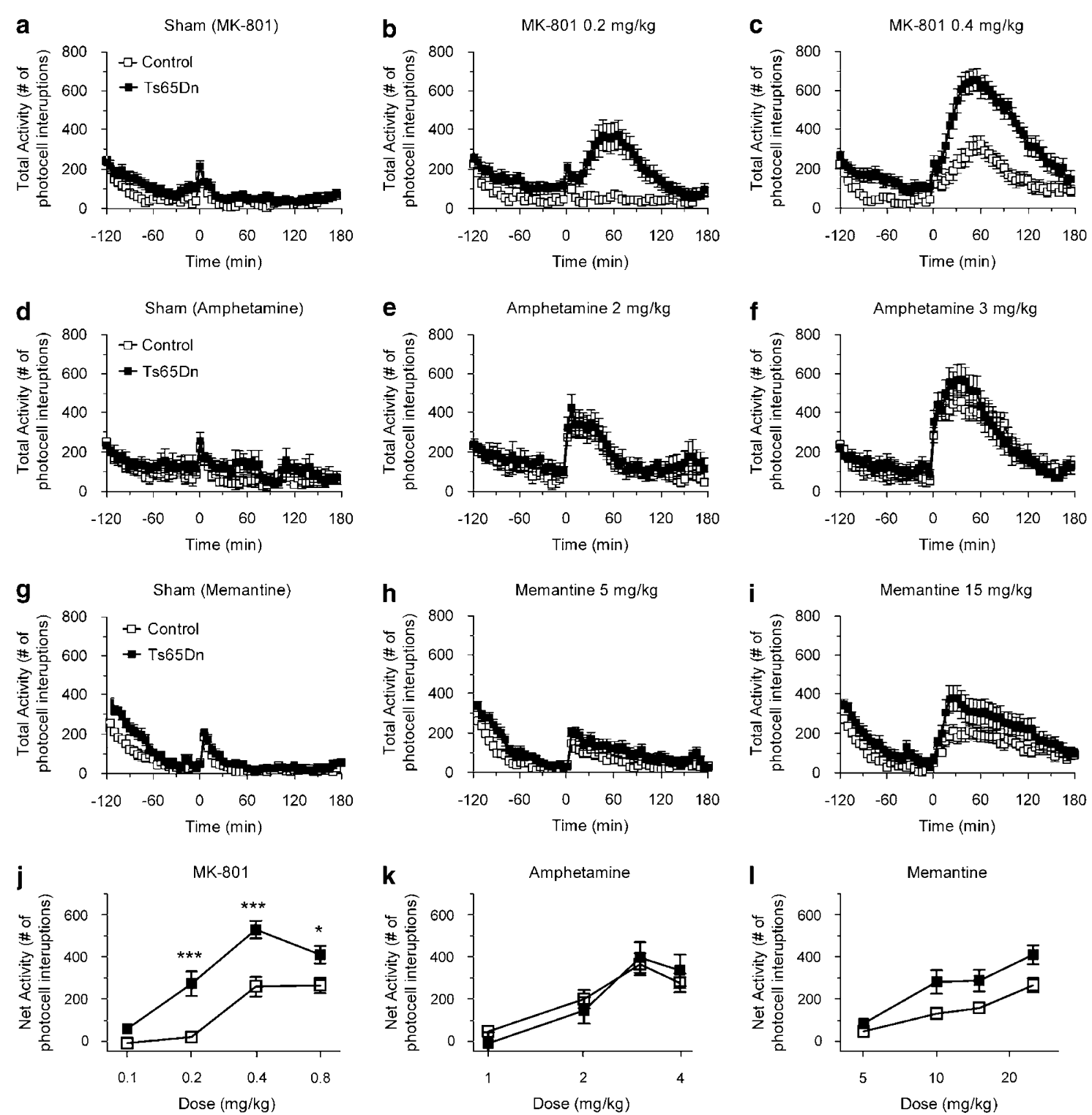

Figure I Ts65Dn mice display an increased sensitivity to MK-80I and memantine. (a-i) Represent total locomotor activity ( \pm SEM) as a function of time. $(\mathrm{a}, \mathrm{b}$, and c) Ts65Dn $(n=15)$ and euploid control mice $(n=15)$ were injected with saline (Sham) or MK-80I $(0.2$ and $0.4 \mathrm{mg} / \mathrm{kg}$, respectively) at time $=0$, $(\mathrm{d}, \mathrm{e}$, and $\mathrm{f}) \operatorname{Ts} 65 \mathrm{Dn}(n=10)$ and euploid control mice $(n=10)$ were injected with amphetamine $(2 \mathrm{and} 3 \mathrm{mg} / \mathrm{kg})$ to test the specificity of the MK-80 I effect. ( $g$, h, and i) Ts65Dn ( $n=15)$ and euploid control mice $(n=15)$ were injected with memantine (5 and $25 \mathrm{mg} / \mathrm{kg})$. (j, k, and I) Represent dose-response relationships for the increases in locomotor activity produced by MK-80I, amphetamine, and memantine injections, respectively. Genotype had a significant effect on the amount of locomotor activity produced by MK-80I and memantine, but not amphetamine.

exposing the mice for $3 \mathrm{~min}$ to the context (Med Associates, St. Albans, VT, Modular Mouse Test Chamber) serving as a conditioning stimulus, followed by an electric shock $(2 \mathrm{~s}$, $0.7 \mathrm{~mA}$, constant electric current) representing the unconditioned stimulus (context-shock protocol). The memory test was performed $24 \mathrm{~h}$ later, by re-exposing the mice to the same context. Freezing, defined as a species-specific defensive reaction characterized by lack of movement besides respiration and heartbeat, associated with crouching posture (Blanchard and Blanchard, 1969; Bolles and Riley, 1973), was used as an indicator of learning, and assessed for $180 \mathrm{~s}$, every $9 \mathrm{~s}$ by two trained observers aware of the mouse genotypes but blind to the pharmacological agent being injected. (We have not attempted to blind the experimenters to genotype because, typically, Ts65Dn mice can be identified by a trained observer with a reasonable degree of accuracy by simple visual inspection.) The mean number of observations indicating freezing behavior was expressed as percentage of freezing in relation to the total number of observations. All experiments were videotaped for archival purposes.

In one set of experiments, one group of each genotype received a $5 \mathrm{mg} / \mathrm{kg}$ i.p. injection of memantine in the first and second day of the experiment $15 \mathrm{~min}$ before exposure to the context, whereas another group of Ts65Dn and control euploid mice received a saline injection of the same volume. To control for potential nonspecific effects of memantine on freezing behavior, we performed a separate set of 
experiments in which separate groups of mice were exposed to an immediate electric shock (also $2 \mathrm{~s}, 0.7 \mathrm{~mA}$, constant electric current) followed by 3 min exposure to the context (shock-context protocol). Mice exposed to a shock-context protocol such as this typically do not acquire conditioned fear despite exposure to the shock (Fanselow, 1980; Milanovic et al, 1998). Finally, as an attempt to distinguish whether the effects of memantine on the mice was related primarily to the acquisition of memory (fear conditioning) or memory retrieval during the context test, we performed experiments in which the mice received only one memantine injection either before the fear conditioning or before the context test.

The two main reasons for choosing a memantine dose of $5 \mathrm{mg} / \mathrm{kg}$ in the present study were (1) in a previously published study on the effect of memantine in the APP23 mouse model of AD, Van Dam et al (2005) used 2 and $10 \mathrm{mg} / \mathrm{kg}$ of memantine, which puts $5 \mathrm{mg} / \mathrm{kg}$ roughly in the middle of this range; (2) if one uses information available at the United States FDA website (http://www.fda.gov/cber/ gdlns/dose.htm) to calculate Human Equivalent Doses, $5 \mathrm{mg} / \mathrm{kg}$ in mice converts to $28 \mathrm{mg}$ for a person weighing $70 \mathrm{~kg}$. The dose of memantine used by most physicians in clinical practice is $20-30 \mathrm{mg} / \mathrm{day}$, which puts $28 \mathrm{mg}$ (the human equivalent dose to $5 \mathrm{mg} / \mathrm{kg}$ in mice) within a potentially clinically relevant range. This dose equivalency is also supported by various published and unpublished studies that related tissue concentrations of memantine in humans at therapeutic dose levels with those achieved after administration in laboratory animals (recently reviewed by Wenk et al, 2006).

\section{Statistics}

Data were expressed as mean and standard error of the mean (SEM). The number of photocell interruptions within a time window (between 30 and $80 \mathrm{~min}$ after injections of MK-801, and between 15 and $50 \mathrm{~min}$ after injections of amphetamine and memantine) was averaged to obtain a response peak for individual mice. (Amphetamine and memantine pharmacological responses generally peaked earlier than the MK-801 responses.) To determine the net activities (Figure 1c, f, and i), the saline peak was subtracted from the locomotor responses of individual mice for each dose of MK-801, amphetamine, or memantine. The net locomotor activity dose response was analyzed by a twoway repeated measures analysis of variance (RM ANOVA) (Statistica 7.0, Stat-soft, Tulsa, OK). Fisher protected least significant difference (PLSD) post hoc test was performed for all significant RM ANOVA. Performances on the fear conditioning protocol of Ts65Dn and control mice that received either memantine or saline injections were compared by two-way ANOVA, with genotype and drug treatment as the factors. Post hoc multiple comparisons were also done by Fisher's PLSD tests. In all figures, statistically significant differences between group means was expressed as $*, * *, * * *$, for $p<0.05, p<0.01$, and $p<0.001$, respectively. In Figure 3 , the symbols $\dagger$ and $\dagger+\dagger$ ( $p<0.05$ and $p<0.001$, respectively) were used to denote statistically significantly differences in mean freezing levels between the Ts65Dn Sal/Sal group and the Ts65Dn Mem/Sal or Ts65Dn Mem/Mem group.

\section{RESULTS}

Ts65Dn Mice are More Sensitive to MK-801 Stimulatory Effects on Locomotor Activity as Compared to Control Euploid Mice

Results from experiments with MK-801 on Ts65Dn mice are illustrated in Figure 1. At $0.2 \mathrm{mg} / \mathrm{kg}, \mathrm{MK}-801$ did not affect control mice, but had a measurable stimulatory effect on Ts65Dn mice (Figure 1b). MK-801 injections of $0.4 \mathrm{mg} / \mathrm{kg}$ produced increased locomotor activity in both Ts65Dn and control mice. However, the effect of MK-801 was more pronounced on Ts65Dn mice than on control euploid mice (Figure 1c). The complete set of results is summarized in Figure $1 \mathrm{j}$, which is a comparative representation of the net locomotor responses (mean $\pm S E M)$ to the four doses of MK-801. Two-way RM ANOVA of our data showed that both genotype $\left(\mathrm{F}_{(1,28)}=33.195,{ }^{*} p<0.0001\right)$ and $\mathrm{MK}-801$ dose $\left(\mathrm{F}_{(3,84)}=49.120,{ }^{\star} p<0.0001\right)$ had significant effects $\left(^{*}\right)$ on locomotor activity. A significant interaction between genotype and MK-801 dose was also detected $\left(\mathrm{F}_{(3,84)}=3.627,{ }^{*} p=0.0162\right)$. Fisher PLSD post hoc tests showed that the locomotor stimulation induced by $0.2,0.4$, and $0.8 \mathrm{mg} / \mathrm{kg}$ injections of MK-801 were significantly larger for Ts65Dn mice than for control mice $\left({ }^{*} p=0.0004\right.$, ${ }^{\star} p=0.0003$, and ${ }^{*} p=0.0297$, respectively).

To test for the selectivity of the MK-801 effect, we have injected a second group of male Ts65Dn $(n=10)$ and control mice $(n=10)$ with pure saline (saline-control) or saline containing amphetamine at four different doses on different days (Figure 1d, e, and $\mathrm{f}$ ). In contrast to the results from MK-801 injections, the locomotor stimulatory effects of amphetamine were dose-dependent $\left(\mathrm{F}_{(1,18)}=46.256\right.$, $\left.{ }^{*} p<0.0001\right)$, but not genotype-dependent $\left(\mathrm{F}_{(1,18)}=0.006\right.$, $p=0.9405$ ) (Figure $1 \mathrm{k}$ ). These results, as well as the results for MK-801, are similar to those reported by Miyakawa et al (2003) on the conditional CaN null-mutant mice.

We then investigated the effects of the drug memantine on a third group of Ts65Dn $(n=15)$ and euploid control mice $(n=15)$. These experiments were performed to answer two questions: (1) whether memantine, which also functions as an open channel blocker of NMDARs, also have a more pronounced effect on Ts65Dn mice compared to euploid control animals and (2) whether there was a potentially therapeutically relevant dose at which administration of this compound would not produce significant psychotomimetic effects on mice. Results for these experiments are illustrated in Figure 1g, h, and 1. At $5 \mathrm{mg} / \mathrm{kg}$ (Figure 1h), memantine's stimulatory effects on Ts65Dn and control euploid mice are just slightly above those of baseline saline injections (Figure 1g). At $25 \mathrm{mg} / \mathrm{kg}$ (Figure 1i), there is an increase in locomotor activity following the injection of memantine. Similar to MK-801, there seems to be a greater locomotor response by Ts65Dn mice than by control animals (Figure 11). Also similar to MK-801, analysis of the data showed that both genotype $\left(\mathrm{F}_{(1,28)}=8.112,{ }^{\star} p=0.0081\right)$ and memantine dose $\left(F_{(3,84)}=38.875,{ }^{\star} p<0.0001\right)$ had significant effects on locomotor activity. At the dose range of memantine used in this study, the interaction between genotype and dose, however, did not reach significance $\left(\mathrm{F}_{(3,84)}=1.850, p=0.1408\right)$. In addition, post hoc tests fail to show significance for any individual dose of memantine 
$(5 \mathrm{mg} / \mathrm{kg}, \quad p=0.6433 ; \quad 10 \mathrm{mg} / \mathrm{kg}, \quad p=0.0683 ; \quad 15 \mathrm{mg} / \mathrm{kg}$, $p=0.1152 ; 25 \mathrm{mg} / \mathrm{kg}, p=0.0815)$.

Acute Memantine Injections Selectively Improve the Behavioral Performance of 4- to 6-Month-Old Ts65Dn Mice in a Test of Learning and Memory

We used a simple fear conditioning protocol to test the capacity for contextual memory of 4- to 6-month-old Ts65Dn mice compared to euploid control mice of the same age. During the context test, saline-injected control mice $(n=10)$ displayed a larger percentage of freezing compared to saline-injected Ts65Dn mice $(n=10)$ (Figure 2a). Therefore, we investigated whether the uncompetitive antagonist memantine might rescue this phenotype. We found that memantine-treated Ts65Dn mice $(n=10)$ displayed freezing at a comparable percentage to both saline-injected and memantine-treated control animals $(n=10)$. Two-way ANOVA revealed that both genotype $\left(\mathrm{F}_{(1,36)}=21.009,{ }^{*} p<0.0001\right)$ and drug treatment $\left(\mathrm{F}_{(1,36)}=5.764,{ }^{*} p=0.0216\right)$ had significant effects on the percentage of freezing during the context test. In addition, we detected a significant interaction between genotype and drug treatment $\left(\mathrm{F}_{(1,36)}=6.191,{ }^{\star} p=0.0176\right)$, which indicate a genotype-dependent drug response to the dose of memantine used in this study. Post hoc tests confirmed that, among the two groups that received saline injections, euploid control mice displayed a significantly larger percentage of freezing during the context test than Ts65Dn mice $\left({ }^{*} p<0.0001\right)$. In contrast, among the mice that received memantine injections, there was no significant difference in freezing behavior between control and Ts65Dn mice $(p=0.1471)$. Most importantly, there were no significant differences between the two groups of euploid control mice $(p=0.9511)$ or between the Ts65Dn mice that received memantine injections and the euploid control mice that received only saline injections $(p=0.1315)$. Finally, both the euploid control mice $\left({ }^{\star} p<0.0001\right)$ and the Ts65Dn mice $\left({ }^{*} p=0.0014\right)$ that received memantine injections displayed freezing behavior for a significantly larger percentage of time during the context test than salineinjected Ts65Dn mice.

In order to control for potential nonspecific effects of memantine on freezing behavior, we performed a shockcontext experiment using an additional four groups of mice. As in the previous experiment, these groups consisted of saline-injected Ts65Dn $(n=10)$ and euploid control $(n=10)$ mice, in addition to memantine-treated Ts65Dn $(n=10)$ and control euploid mice $(n=10)$. In these experiments, mice were exposed to an immediate electric shock $(2 \mathrm{~s})$ followed by $3 \mathrm{~min}$ exposure to the context. Previous studies in the field of fear conditioning (Fanselow, 1980; Milanovic et al, 1998) have shown that mice that are exposed to a shock-context protocol typically do not acquire conditioned fear. Accordingly, we found that all groups displayed less than $10 \%$ freezing behavior during the context test (Figure 2b). In addition, two-way ANOVA did not show any significant genotype $\left(\mathrm{F}_{(1,36)}=2.374\right.$, $p=0.1321)$ or drug effect $\left(\mathrm{F}_{(1,36)}=0.066, p=0.7988\right)$ on the percentage of freezing during the context test.
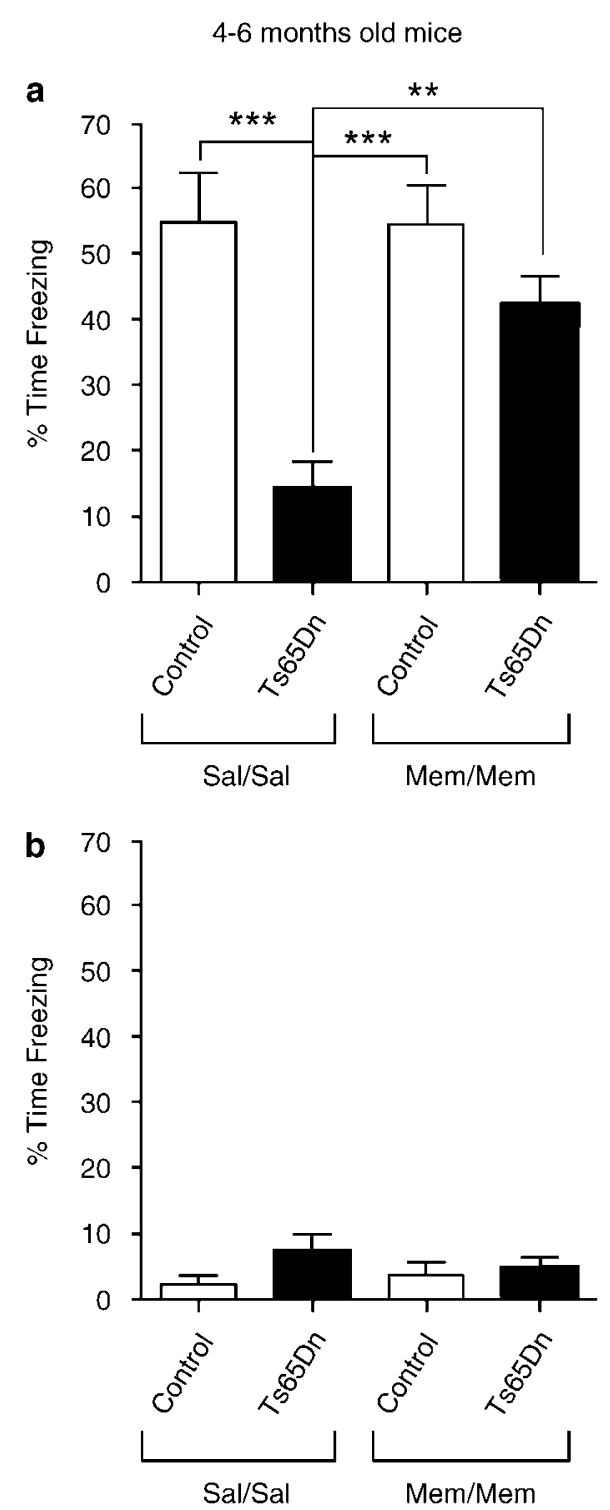

Figure 2 Memantine rescues performance deficits of 4- to 6-month-old Ts65Dn mice on a fear conditioning test. Bar graphs in ( $a$ and b) represent mean percentage freezing $( \pm$ SEM) during the context test. (a) In a context-shock protocol, saline-injected euploid control mice $(n=10)$ displayed freezing for about $50 \%$ of the total time, whereas saline-injected Ts65Dn mice $(n=10)$ displayed freezing behavior for only about 15\% of the total time. In contrast, memantine-treated Ts65Dn mice $(n=10)$ displayed freezing at a comparable percentage to both saline-injected and memantine-treated control animals $(n=10)$. (b) Mice that were exposed to the shock-context protocol, irrespective of genotype, did not acquire conditioned fear, despite exposure to the shock and memantine treatment ( $n=10$ for each group).

\section{One Memantine Injection Prior to the Fear Conditioning Session is Necessary to Produce Memory Enhancement in 4- to 6-Month-Old Ts65Dn Mice}

We also performed experiments in which the mice received only one memantine injection, either $15 \mathrm{~min}$ before the fear conditioning (Mem/Sal group, $n=10$ per genotype) or $15 \mathrm{~min}$ before the context test (Sal/Mem group, $n=10$ per genotype). These experiments were designed to help us define whether the memory/learning enhancing effect of memantine on Ts65Dn mice was related primarily to the 


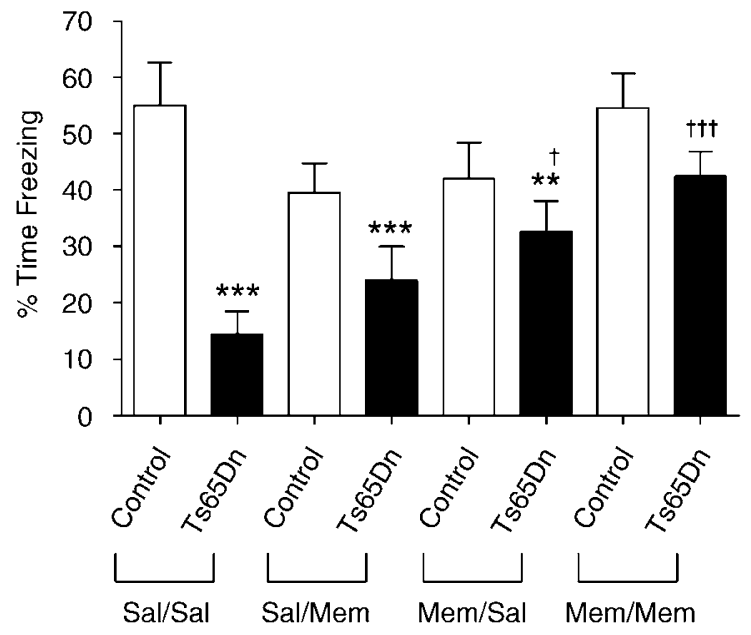

Figure 3 Memantine injection prior to the fear conditioning session is necessary to produce memory enhancement in 4- to 6-month-old Ts65Dn mice. Bar graphs represent mean percentage freezing $( \pm$ SEM) during the context test. In this graph, Sal/Sal represents mice that received saline injections before being exposed to the conditioning stimulus and before being re-exposed to the conditioning stimulus on the following day $(n=10$ for both genotypes) (data reproduced from Figure 2a). Sal/Mem represents mice that were injected with saline on day I and memantine $(5 \mathrm{mg} / \mathrm{kg}$; $n=10$ for both genotypes) on day 2 . Mem/Sal represents mice that were injected with memantine $(5 \mathrm{mg} / \mathrm{kg} ; n=10$ for both genotypes) on day I and saline on day 2 . These mice displayed significantly more freezing than the Sal/Sal group. Mem $/ \mathrm{Mem}$ are mice that received $5 \mathrm{mg} / \mathrm{kg}(n=10$ for both genotypes) on days I and 2 (data reproduced from Figure 2a).

acquisition of fear conditioning or memory retrieval during the context test. In Figure 3, we compared the results of these experiments with the previous experiments, in which the mice received two memantine ( $\mathrm{Mem} / \mathrm{Mem}$ group) or two saline injections (Sal/Sal group). Data analysis revealed that both genotype $\left(\mathrm{F}_{(1,72)}=22.578,{ }^{\star} p<0.0001\right)$ and drug treatment schedule $\left(\mathrm{F}_{(3,72)}=3.216,{ }^{*} p=0.0278\right)$ had significant effects on the percentage of freezing during the context test. Post hoc analysis showed that the only form of single injection treatment that produced significantly more freezing on Ts65Dn mice than the Sal/Sal group was the one in which the injection was administered before the fear conditioning session (Ts65Dn Mem/Sal; ${ }^{\star} p=0.0305$ ). Although the percentage of freezing in the Ts65Dn Sal/Mem group was not significantly different from the Ts65Dn Sal/ Sal group $(p=0.2479)$, the percentage of freezing in the Ts65Dn Mem/Sal group was still significantly smaller than that of the control euploid Sal/Sal group $\left({ }^{*} p=0.0073\right)$. Therefore, with the present data, we cannot discount some level of contribution of memantine to the Ts65Dn mice's ability to retrieve information. Still, this selective effect of a memantine injection before the fear conditioning, compared to an injection of this drug before the context test, adds to the shock-context experiment results in helping to exclude the possibility of nonspecific effects of memantine on the freezing behavior of Ts65Dn mice.

Acute Memantine Injections Selectively Improve the Performance of 10- to 14-Month-Old Ts65Dn Mice in the Context Test

To investigate a potential age-dependence of the memory/ learning enhancing effect of memantine on Ts65Dn mice,
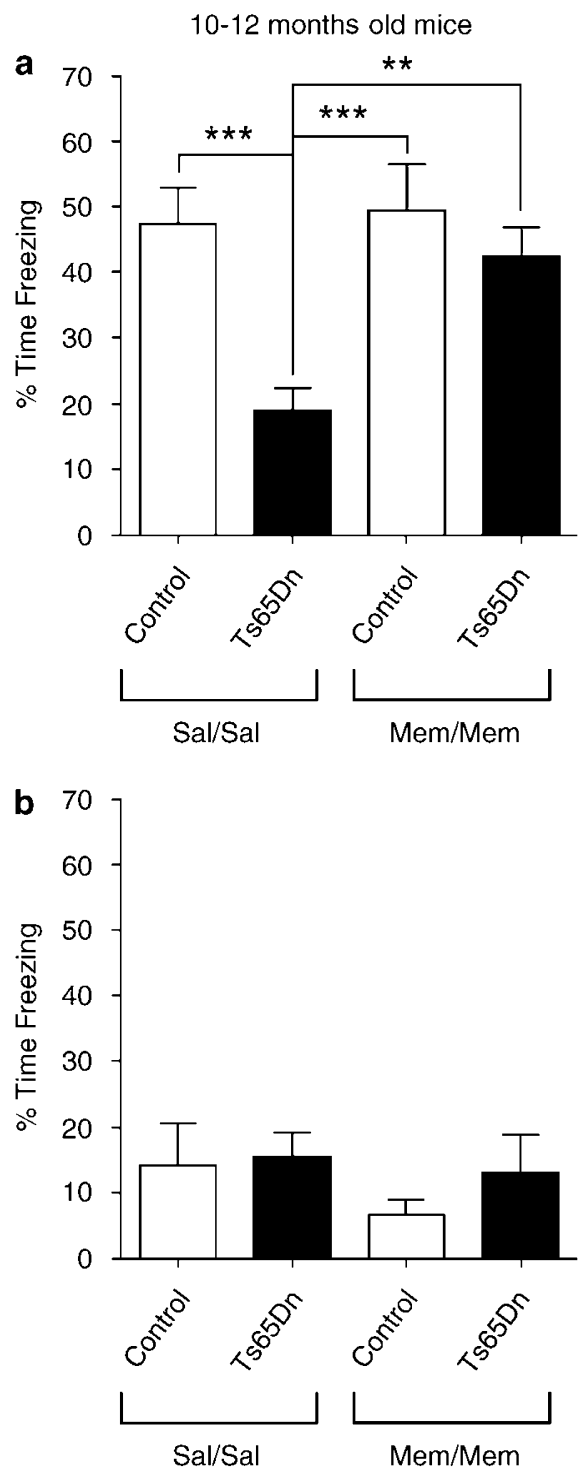

Figure 4 Memantine also rescues performance deficits of 10- to 12month-old Ts65Dn mice on a fear conditioning test. Bar graphs in ( $a$ and $b$ ) represent mean percentage freezing ( \pm SEM) during the context test. (a) In a context-shock protocol, saline-injected euploid control mice $(n=10)$ displayed freezing for about 50\% of the total time, saline-injected Ts65Dn mice $(n=10)$ displayed freezing behavior for only about $20 \%$ of the total time. Memantine-treated Ts65Dn mice $(n=10)$ displayed a comparable percentage of freezing behavior as saline-injected and memantine-treated control animals $(n=10)$. (b) Mice that were exposed to the shock-context protocol, irrespective of genotype, did not acquire conditioned fear $(n=8$ for each group).

we repeated the same fear conditioning protocol used with 4- 6-month-old Ts65Dn mice on separate groups of Ts65Dn mice ranging between 10 and 14 months of age (Figure $4 \mathrm{a}$ ). As with 4- to 6-month-old mice, we found that both genotype $\left(\mathrm{F}_{(1,36)}=11.356,{ }^{*} p=0.0018\right)$ and drug treatment $\left(\mathrm{F}_{(1,36)}=5.860,{ }^{*} p=0.0207\right)$ had significant effects on the percentage of freezing during the context test. We also detected a significant interaction between genotype and drug treatment $\left(\mathrm{F}_{(1,36)}=4.166,{ }^{*} p=0.0486\right)$. Among the two groups that received saline injections, euploid control mice $(n=10)$ displayed a significantly larger percentage of freezing during the context test than Ts65Dn mice $(n=10$; 
$\left.{ }^{*} p=0.0005\right)$. In contrast, among the mice that received memantine injections, there was no significant difference in freezing behavior between control $(n=10)$ and Ts65Dn mice $(n=10 ; p=0.3536)$. There were also no significant differences between the two groups of euploid control mice $(p=0.7899)$ or between the Ts65Dn mice that received memantine injections and the euploid control mice that received only saline injections $(p=0.5064)$. Furthermore, both the euploid controls $\left({ }^{*} p=0.0002\right)$ and the Ts65Dn mice $\left({ }^{*} p=0.0032\right)$ that received memantine injections displayed freezing behavior for a significantly larger percentage of time during the context test than salineinjected Ts65Dn mice.

We then performed shock-context experiments on four additional groups of 10- to 14-month-old mice. Two of these groups consisted of saline-injected control $(n=8)$ and Ts65Dn mice $(n=8)$. The two additional groups were comprised of memantine-treated (two $5 \mathrm{mg} / \mathrm{kg}$ injections) Ts65Dn $(n=8)$ and control euploid mice $(n=8)$. We found that all groups of 10 - to 14-month-old mice displayed slightly more freezing behavior than the 4- to 6-month-old mice (Figure 4b). The percentage of freezing for any individual group, however, was still no larger than $15 \%$ and, similar to the findings with 4 - to 6-month-old mice, we did not detect any significant genotype $\left(\mathrm{F}_{(1,36)}=0.601\right.$, $p=0.4445)$ or drug effect $\left(\mathrm{F}_{(1,36)}=1.069, p=0.3100\right)$ in this experiment.

\section{DISCUSSION}

Based on available information on the human chromosome 21 , mouse chromosome 16, and mouse models of DS, we proposed the hypothesis that NMDAR function may be pathologically affected in persons with DS and in the mouse model of DS known as Ts65Dn. If such tonic changes in NMDAR function are indeed taking place in Ts65Dn mice, this potentially could lead to a decrease in the 'signal-tonoise ratio' during neuroplasticity events related to learning and memory, as well as NMDAR-mediated glutamate excitotoxicity. This is the same scenario that has been described in the glutamatergic hypothesis for AD (Danysz and Parsons, 2003; Wenk et al, 2006). In the present study, we found that, consistent with this hypothesis, Ts65Dn mice display an increased sensitivity to MK-801. Furthermore, acute injections of memantine rescued performance deficits of Ts65Dn mice on a Pavlovian fear conditioning test.

The Ts65Dn mouse was created almost two decades ago at The Jackson Laboratory (Davisson et al, 1990). At the time this work was submitted, 110 PubMed-indexed publications (as well as more than a dozen book chapters and other nonindexed publications) have been dedicated to the study of this mouse, which is widely accepted as the most complete mouse model for DS currently available. Although Ts65Dn mice do not present all the features associated with DS (for example, they do not develop congenital heart defects or the characteristic AD-type pathology), they display many DS-phenotype analogs, such as significant learning deficits in specific behavioral tasks, craniofacial dysmorphogenesis, motor dysfunction, and age-dependent loss of cholinergic markers in basal forebrain cholinergic neurons (reviewed in Davisson and Costa, 1999; Patterson and Costa, 2005). In addition, findings from studies on Ts65Dn mice have had a significant predictive value. For instance, it was the finding of learning deficits on putatively hippocampus-dependent tasks in these mice (such as the Morris water maze and context discrimination) that led Pennington et al (2003) to launch the first comprehensive neuropsychological assessment of individuals with DS to include a large component of hippocampus-dependent measures. This pivotal work indeed revealed a disproportionally large deficit in hippocampus-dependent learning measures in persons with DS.

Hyde and Crnic (2001) have demonstrated that Ts65Dn mice older than 5 months show deficits in context discrimination learning, which is a behavioral task related to the fear conditioning protocol we have used here. Both context discrimination learning and contextual fear conditioning have been shown to be dependent on hippocampal function (Hyde et al, 2001; Sananbenesi et al, 2002). Hyde et al (2001) also have found that Ts65Dn mice display no abnormality in sensitivity to electrical shock compared to control euploid mice. These shock sensitivity experiments were performed in the same institution as the present study, using virtually the same equipment, and on mice of overlapping age as those used here. Therefore, we have no reason to suspect that a genotype-dependent difference in shock sensitivity could provide an alternative explanation to our results.

Memantine has been available in Germany and some other European Union countries for more than two decades. In 2004, it was approved for moderate to severe dementia by the FDA (Danysz and Parsons, 2003; Sonkusare et al, 2005). This drug is generally viewed as an uncompetitive antagonist of NMDARs with moderate affinity that reportedly inhibits the pathological functions of NMDARs while leaving unaffected physiological processes in learning and memory. Recently, however, Creeley et al (2006) questioned the notion that memantine has any unique properties, when compared to other NMDAR antagonists such as MK-801, in terms of not disturbing normal behavior. These authors administered memantine to adult rats, using doses at or below the dose required for neuroprotection from an injection of kainic acid, and evaluated the effects of these doses of memantine on activity, sensorimotor performance, and on tests of spatial memory acquisition and retention. Because they detected locomotor disturbances severe enough to preclude testing for learning and memory effects at neuroprotective doses $(20 \mathrm{mg} / \mathrm{kg})$, they questioned whether memantine's therapeutic efficacy in $\mathrm{AD}$ is indeed derived from its NMDAR antagonism, or whether it comes from actions on other receptors, such as $\alpha 7$ nicotinic receptors.

In the present study, we confirmed the findings of Creeley et al (2006) that memantine at doses as low as $10 \mathrm{mg} / \mathrm{kg}$ can produce increases in locomotion that may be indicative of psychotomimetic activity in rodents. We have also found that Ts65Dn mice were significantly more sensitive to memantine than control euploid mice, although the genotype dependence of this effect was not as marked as that for MK-801. At the dose we have chosen for our fear conditioning experiments $(5 \mathrm{mg} / \mathrm{kg})$, however, there was no significant genotype-dependent increase in locomotor activity that could account for our findings. In addition, 
although Aracava et al (2005) have shown that memantine can block $\alpha 7$ receptors at lower concentrations than those necessary to produce measurable blockage of NMDARs, previous observations by Paylor et al (1998) had shown that $\alpha 7$ nicotinic receptors have no significant impact on baseline fear conditioning responses in mice. Therefore, unless $\alpha 7$ receptors in Ts65Dn mice have a different functional role than in euploid control animals, current behavioral data do not support a role for these receptors in the enhancement of fear conditioning responses that we observed in Ts65Dn mice after acute injections of memantine.

We should emphasize that, although we have used molecular information to hypothesize a memory/learning enhancing effect of memantine on Ts65Dn mice, and although our findings are consistent with the proposed hypothesis, our data cannot exclude alternative pathophysiologies or mechanisms of drug action. For example, recently, De Felice et al (2007) have found that $\mathrm{A} \beta$ oligomers (also known as ADDLs) stimulated excessive formation of reactive oxygen species (ROS) through a mechanism requiring NMDAR activation. Because the APP gene is represented in three copies and overexpressed by $50 \%$ in Ts65Dn mice, it is possible that these animals present an excess of ADDLs, which might produce not only chronic ROS formation but also reversible deficits in learning and memory. Additionally, studies by our group (Costa and Grybko, 2005) and others (Kleschevnikov et al, 2004) provided evidence of increases in $\mathrm{GABA}_{\mathrm{A}}$-receptormediated inhibition or in plasticity of the inhibitory circuitry in Ts65Dn mice compared to euploid control mice. Based on one set of population field potential recording experiments, Kleschevnikov et al (2004) proposed that such enhanced $\mathrm{GABA}_{\mathrm{A}}$-receptor-mediated processes in the hippocampus of Ts65Dn mice may produce decreased NMDAR function. Obviously, the rigorous demonstration of decreased NMDAR function would conflict with the main hypothesis proposed in the present work. However, these experimental results are difficult to interpret, given that they were not obtained under voltage-clamp conditions and complete pharmacological isolation of NMDAR-mediated currents. Furthermore, these experiments were not designed to detect a potentially 'leaky' state of the NMDARs, in which ambient levels of glutamate would tonically activate NMDARs and lead to a decreased 'signal-to-noise ratio' during neuroplasticity events, as proposed by Danysz and Parsons (2003) for AD.

In light of our findings, some clear directions for future studies include: (1) search for the most effective dose and injection regimen for memantine in Ts65Dn mice; (2) investigation of molecular correlates, such as in NMDAR phosphorylation levels and ion channel gating kinetics; (3) study of the chronic exposure of Ts65Dn mice to this compound and (4) investigation of a potential neuroprotective role of memantine in Ts65Dn mice.

Recently, Fernandez et al (2007) demonstrated that memory and learning deficits in Ts65Dn mice can be reversed by the chronic administration of clinically subepileptogenic doses of $\mathrm{GABA}_{\mathrm{A}}$ receptor antagonists. To our knowledge, however, the present work is the first instance in which the acute injection of a pharmacological agent has improved the behavioral performance of
Ts65Dn mice in a test of learning and memory. These results are quite exciting from a potential therapeutic perspective, given the current status of memantine as an FDA-approved drug and given that the dose of memantine used here is likely to be therapeutically relevant.

\section{DISCLOSURE/CONFLICTS OF INTEREST}

Although, at present, none of the authors have any conflict of interest to disclose, the corresponding author is currently applying for an investigator initiated grant by Forest Research Institute to fund a pilot clinical trial on the potential cognitive effects of memantine in young adults with Down syndrome as a follow-up study to the preclinical research presented here.

\section{ACKNOWLEDGEMENTS}

This work was supported by the Anna \& John J Sie Foundation, the Mile High Down syndrome Association, the Colorado Springs Down Syndrome Association, the Coleman Institute for Cognitive Disabilities, and NIH grant HD37113.

\section{REFERENCES}

Aracava Y, Pereira EF, Maelicke A, Albuquerque EX (2005). Memantine blocks alpha7* nicotinic acetylcholine receptors more potently than $N$-methyl-D-aspartate receptors in rat hippocampal neurons. J Pharmacol Exp Ther 312: 1195-1205.

Arron JR, Winslow MM, Polleri A, Chang CP, Wu H, Gao X et al (2006). NFAT dysregulation by increased dosage of DSCR1 and DYRK1A on chromosome 21. Nature 441: 595-600.

Bardgett ME, Boeckman R, Krochmal D, Fernando H, Ahrens R, Csernansky JG (2003). NMDA receptor blockade and hippocampal neuronal loss impair fear conditioning and position habit reversal in C57Bl/6 mice. Brain Res Bull 60: 131-142.

Blanchard RJ, Blanchard DC (1969). Crouching as an index of fear. J Comp Physiol Psychol 67: 370-375.

Bolles RC, Riley AL (1973). Freezing as an avoidance response: another look at the operant-respondent distinction. Learn Motiv 4: 268-275.

Chen HS, Pellegrini JW, Aggarwal SK, Lei SZ, Warach S, Jensen FE et al (1992). Open-channel block of $N$-methyl-D-aspartate (NMDA) responses by memantine: therapeutic advantage against NMDA receptor-mediated neurotoxicity. J Neurosci 12: 4427-4436.

Costa ACS, Grybko M (2005). Deficits in hippocampal CA1 LTP induced by TBS but not HFS in the Ts65Dn mouse, a model of Down syndrome. Neurosci Lett 382: 317-322.

Creeley C, Wozniak DF, Labruyere J, Taylor GT, Olney JW (2006). Low doses of memantine disrupt memory in adult rats. J Neurosci 26: 3923-3932.

Danysz W, Parsons CG (2003). The NMDA receptor antagonist memantine as a symptomatological and neuroprotective treatment for Alzheimer's disease: preclinical evidence. Int J Geriatr Psychiatry 18: S23-S32.

Davisson MT, Costa ACS (1999). Mouse models of Down syndrome. In Popko B (ed). Advances in Neurochemistry Vol. 9. Kluwer Academic/Plenum: New York. pp 297-327.

Davisson MT, Schmidt C, Akeson EC (1990). Segmental trisomy of murine chromosome 16: a new model system for studying Down syndrome. Prog Clin Biol Res 360: 263-280. 
De Felice FG, Velasco PT, Lambert MP, Viola K, Fernandez SJ, Ferreira ST et al (2007). Abeta oligomers induce neuronal oxidative stress through an $\mathrm{N}$-methyl-D-aspartate receptordependent mechanism that is blocked by the Alzheimer drug memantine. J Biol Chem 282: 11590-11601.

Ermak G, Davies KJ (2003). DSCR1(Adapt78) - a Janus gene providing stress protection but causing Alzheimer's disease? IUBMB Life 55: 29-31.

Fanselow MS (1980). Conditional and unconditional components of post-shock freezing. Pavlovian J Biol Sci 15: 177-182.

Fernandez F, Morishita W, Zuniga E, Nguyen J, Blank M, Malenka RC et al (2007). Pharmacotherapy for cognitive impairment in a mouse model of Down syndrome. Nat Neurosci 10: $411-413$.

Gardiner K (2003). Predicting pathway perturbations in Down syndrome. J Neural Transm Suppl 67: 21-37.

Goate A, Chartier-Harlin MC, Mullan M, Brown J, Crawford F, Fidani L et al (1991). Segregation of a missense mutation in the amyloid precursor protein gene with familial Alzheimer's disease. Nature 349: 704-706.

Hyde LA, Crnic LS (2001). Age-related deficits in context discrimination learning in Ts65Dn mice that model Down syndrome and Alzheimer's disease. Behav Neurosci 115: 12391246.

Hyde LA, Frisone DF, Crnic LS (2001). Ts65Dn mice, a model for Down syndrome, have deficits in context discrimination learning suggesting impaired hippocampal function. Behav Brain Res 118: 53-60.

Kahlem P, Sultan M, Herwig R, Steinfath M, Balzereit D, Eppens B et al (2004). Transcript level alterations reflect gene dosage effects across multiple tissues in a mouse model of Down syndrome. Genome Res 14: 1258-1267.

Kleschevnikov AM, Belichenko PV, Villar AJ, Epstein CJ, Malenka RC, Mobley WC (2004). Hippocampal long-term potentiation suppressed by increased inhibition in the Ts65Dn mouse, a genetic model of Down syndrome. J Neurosci 24: 8153-8160.

Lange AW, Rothermel BA, Yutzey KE (2005). Restoration of DSCR1 to disomy in the trisomy 16 mouse model of Down syndrome does not correct cardiac or craniofacial development anomalies. Dev Dyn 233: 954-963.

Leverenz JB, Raskind MA (1998). Early amyloid deposition in the medial temporal lobe of young Down syndrome patients: a regional quantitative analysis. Exp Neurol 150: 296-304.

Lieberman DN, Mody I (1994). Regulation of NMDA channel function by endogenous $\mathrm{Ca}(2+)$-dependent phosphatase. Nature 369: 235-239.
Liu DP, Schmidt C, Billings T, Davisson MT (2003). Quantitative PCR genotyping assay for the Ts65Dn mouse model of Down syndrome. Biotechniques 35: 1170-1174.

Mann DM, Jones D, Prinja D, Purkiss MS (1990). The prevalence of amyloid (A4) protein deposits within the cerebral and cerebellar cortex in Down's syndrome and Alzheimer's disease. Acta Neuropathol (Berl) 80: 318-327.

Milanovic S, Radulovic J, Laban O, Stiedl O, Henn F, Spiess J (1998). Production of the Fos protein after contextual fear conditioning of C57BL/6N mice. Brain Res 784: 37-47.

Miyakawa T, Leiter LM, Gerber DJ, Gainetdinov RR, Sotnikova TD, Zeng $\mathrm{H}$ et al (2003). Conditional calcineurin knockout mice exhibit multiple abnormal behaviors related to schizophrenia. Proc Natl Acad Sci USA 100: 8987-8992.

Patterson D, Costa AC (2005). Down syndrome and genetics - a case of linked histories. Nat Rev Genet 6: 137-147.

Paylor R, Nguyen M, Crawley JN, Patrick J, Beaudet A, OrrUrtreger A (1998). Alpha7 nicotinic receptor subunits are not necessary for hippocampal-dependent learning or sensorimotor gating: a behavioral characterization of Acra7-deficient mice. Learn Mem 5: 302-316.

Pennington BF, Moon J, Edgin J, Stedron J, Nadel L (2003). The neuropsychology of Down syndrome: evidence for hippocampal dysfunction. Child Dev 74: 75-93.

Sananbenesi F, Fischer A, Schrick C, Spiess J, Radulovic J (2002). Phosphorylation of hippocampal Erk-1/2, Elk-1, and p90-Rsk-1 during contextual fear conditioning: interactions between Erk-1/2 and Elk-1. Mol Cell Neurosci 21: 463-476.

Sonkusare SK, Kaul CL, Ramarao P (2005). Dementia of Alzheimer's disease and other neurodegenerative disorders - memantine, a new hope. Pharmacol Res 51: 1-17.

St George-Hyslop PH, Tanzi RE, Polinsky RJ, Haines JL, Nee L, Watkins PC et al (1987). The genetic defect causing familial Alzheimer's disease maps on chromosome 21. Science 235: 885-890.

Van Dam D, Abramowski D, Staufenbiel M, De Deyn PP (2005). Symptomatic effect of donepezil, rivastigmine, galantamine and memantine on cognitive deficits in the APP23 model. Psychopharmacology (Berl) 180: 177-190.

Wenk GL, Parsons CG, Danysz W (2006). Potential role of $\mathrm{N}$ methyl-D-aspartate receptors as executors of neurodegeneration resulting from diverse insults: focus on memantine. Behav Pharmacol 17: 411-424.

Zigman W, Schupf N, Haveman M, Silverman W (1997). The epidemiology of Alzheimer disease in intellectual disability: results and recommendations from an international conference. J Intellect Disabil Res 41: 76-80. 